\title{
Motivations for selecting Cross-Border E-Commerce as a Foreign Market Entry
}

Mode

\section{Introduction}

The rapid growth of e-commerce in China provides additional channels and innovative options for foreign firms to enter the Chinese market (McDermott \& Payvision, 2015), which could be critical for the long-term growth of many of those firms given China's size and diverse nature (Johnson \& Telli, 2008). Cross-border e-commerce (CBEC) can be seen as one of the new entry modes, which is gaining particular popularity in China due to the predominant online shopping behavior and the rapid rise of e-commerce activities in the country.

Any firm that intends to expand its business outside their home country has to make a strategic choice about entry mode. Conventional concepts used in the internationalization of firms include the Uppsala School model of a stepwise process of foreign market entry proposed by Forsgren and Hogstrom (2007). Examples of possible entry modes are exporting, forming a joint venture, and setting up a "greenfield" wholly owned subsidiary in a foreign country. CBEC is a new model integrating both e-commerce and international trade (Xue, Li, \& Pei, 2016). It could revolutionize the practices, and renew our conceptual understanding, of entry mode selection.

CBEC refers to a cross-border trade completed between different countries via ecommerce (Wang et al., 2015; AliResearch, 2016). Firms need not have any physical presence in the target host-market. Transactions are made via the internet on either the company's own site or a site within a third-party marketplace platform. These sites can be located in either the home or host country. For instance, customers in Malaysia can purchase items from H\&M.com directly, with the items being shipped from warehouses in London. Nevertheless, this form of traffic is expected to be much smaller in volume to traffic on any popular host-country based marketplace platform. For example, Chinese B2C e-commerce is dominated by JD.com and Alibaba's marketplace platforms.

Currently, the industry believes that CBEC in China is at its exponential growth stage (AliResearch, 2016). A recent report shows that the trade volume of CBEC in China reached RMB6.7 trillion ( $\sim$ US $\$ 1$ trillion) in 2016, an increase of $31.6 \%$ over the previous year. It was estimated that trade will reach RMB8.8 trillion ( $\sim$ US $\$ 1.3$ trillion) by 2018 (Jingli, 2017). Development at this stage is marked by the establishment of market leaders with a number of major cross-border e-commerce platforms (e.g., wish.com, vip.com, mia.com), who build resilient ecosystems with the support of various service providers that aim to grow their businesses along with the online platforms (Xu, 2017a). Typical service providers are consulting firms, training firms, and integrated marketing solution providers.

CBEC is playing an important role in transforming traditional international trade and boosting economies $(\mathrm{Xu}, 2017 \mathrm{a})$. In traditional cross-border trade, customers can purchase overseas products through a long supply chain involving several intermediaries. CBEC shortens this supply chain by involving cross-border ecommerce platforms as the intermediaries along the supply chain, which also substantially reduces customers' waiting times (Xu, 2017b). This trend of consumption upgrading is regarded as another driver for the promotion of CBEC (Nielsen, 2017). 
Currently, there is limited understanding of various aspects of CBEC in general and in China in particular. The existing literature (e.g. Liu, Chen, \& Cai, 2015; Xue, Li, \& Pei, 2016; Wang, 2014) has not considered some of the fundamental challenges for firms embarking on a CBEC venture. Questions remaining unanswered include: how are these kinds of cross-border transactions being processed and facilitated? What are the differences between a traditional export and cross-border e-commerce export channel? Why do foreign brands accept and choose this new type of CBEC market entry? What are the main motivations in selecting CBEC as a foreign market entry mode, particularly in China?

We argue that it is vital to investigate the fundamental motivations for firms entering into foreign markets - in this case, China. This will help to develop a better understanding of what makes entering a foreign market successful and what causes failure, particularly relating to the deployment of e-commerce. Such an understanding will facilitate building more successful international business with e-commerce initiatives, which many firms have to consider as internet commerce booms. This research was motivated by a number of international firms having only limited success in entering the Chinese market, particularly with their firm-based e-commerce sites. This article addresses knowledge gaps about this new foreign market entry mode with the main research question being:

\section{What are the key motivations for foreign firms in deploying cross-border e- commerce as a market entry mode?}

Transaction cost theory (TCT) is the most common theoretical basis for examining the decision of foreign market entry mode (Shen, Puig, \& Paul, 2017). According to transaction cost economies, firms select the foreign market entry mode that incurs the least cost of transaction, i.e. the most economic efficient form of international governance that will lead to a better firm performance (Brouthers, Brouthers, \& Werner, 2003). Transaction costs are expenditures that vary independently from the production costs of the products or services exchanged. It may arise in the forms of $e x$ ante costs such as searching and information costs; negotiation and contracture costs while establishing the initial relationship; and ex post transaction costs in managing relationship, monitoring and enforcement costs (Kabadayi, 2011). In an environment where transaction costs are high, TCT predicts that firms tend to internalize the transactions and hence form a vertical integrated governance structure (Williamson, 1985). In terms of foreign market entry mode, firms tend to select an equity-based entry mode to internalize transaction costs. However, CBEC offers a new option for foreign market entry. This study investigates the following questions. What are the motivations for firms to select CBEC? How could a high transaction cost be avoided under CBEC? What elements that increase transaction costs could be mitigated under CBEC?

A vertical integrated governance structure enables a firm to impose a high level of control. Control is essential where trading partners might behave opportunistically, particularly under a high level of market uncertainty. Despite this function of control, there are alternative forms such as relational norms and trust to manage trading partners because "relationships shape expectations" (e.g., Granovetter, 1985; Poppo, Zhou, \& Li, 2016). This case therefore will also examine the role of trust in determining the choice of CBEC. 
Section 2 of the paper consists of a critical review of the theoretical basis and analytical framework for analyzing CBEC. We explain the research methodology, including the context of CBEC and the rationale for the case selection in Section 3. The authors have conducted a case study in the Chinese market; China has one of the most active CBEC markets, in particular, foreign firms have been increasingly dependent on third party marketplace platforms as their key sales channel. IKEA, for example, has run their standalone e-commerce website for many years in China with mixed success but decided to enter the TMall marketplace in 2018.

The usual approach to answer the above research question is to survey or interview foreign brands. But this section also explains the novel research strategy of deploying an in-depth nested case study consisting of a prominent technology provider (TP) and a foreign brand that is one of the TP's clients. Section 4 provides the analysis on the findings and discussions. Conclusions and limitations of this research are presented in Section 5.

\section{Literature review}

\subsection{Theoretical Underpinning for Selection of Foreign Market Entry Modes}

The notion that extra growth and profits cannot be further achieved through operating exclusively in the home market may motivate firms' overseas market-seeking behavior (Root, 1994). Firms that intend to expand their business overseas aim to generate more revenue and also counter foreign rivals protecting their own home market (Watson, 1982). Willcocks (2013) summarizes four objectives of foreign market entry: to seek natural resources, to tap into emerging markets with strong demand, to achieve higher efficiency (in terms of costs), and to seek ideas and talent, thus driving innovation.

Firms select the most desirable entry mode to enter a new foreign market - one of their most important strategic decisions and a critical determinant of a successful foreign operation (Datta, Hemnann, \& Rasheed, 2002; Hill \& Hwang, 1990). Entry mode, as defined by Root (1994), is "an institutional arrangement that makes possible the entry of a firm's products, technology, human skills, management, or other resources into a foreign country." Later scholars describe entry mode as a way of organizing the two pillars of a firm's business in foreign market, i.e. production and marketing (Sharma \& Erramilli, 2004; Morschett, Schramm-Klein, \& Swoboda, 2010). This research relates more to the decision on marketing channel and retail decisions.

Literature indicates that foreign entry requires firms to make two interdependent decisions, i.e. location and degree of control (Buckley \& Casson, 1998; Gatignon \& Anderson, 1988; Datta, Hemnann, \& Rasheed, 2002). The attributes of the host country are key factors here. The context of Chinese e-commerce development will be further analyzed in Section 3.

Root (1994) also identifies fifteen different modes of market entry. On levels of control, these modes can be divided into two categories: equity entry modes and non-equity modes (Anderson \& Gatignon, 1986; Pan \& Tse, 2000). Later scholars classify entry modes into five main categories in order of increasing control: export, license and franchise, alliance, joint venture and wholly owned subsidiary (Johnson \& Telli, 2008; Willcocks, 2013).

Each entry mode can be attractive or unattractive. For example, export is worth considering because it removes the costs of building local operations and can help ramp up overseas sales with the assistance of export intermediaries. However, firms 
need to bear high transport costs and tariffs, and have little control over agents in the host country. When establishing a joint venture partnership, a firm can benefit from its host partner's knowledge and can share the costs and risks with its local partner. However, sharing ownership and control between two and more parties can also lead to disputes and the firm may even lose its core competence. In contrast, a wholly owned subsidiary reduces the risk of losing control and profits, but that subsidiary bear all the risks and costs (Willcocks, 2013).

Scholars have attempted to employ different theoretical perspectives when investigating the antecedents and consequences of entry mode choice. "These divergent theoretical perspectives offer different assumptions about the relative importance of the various factors in the choice of entry mode" (Datta, Hemnann, \& Rasheed, 2002). The most frequently used theories in past literature include Hymer's theory, resource-based view, transaction cost theory (TCT), and eclectic theory.

According to Hymer's theory, the choice of entry mode is driven by a firm's desire to exploit its proprietary advantages in the foreign market. Similarly, theorists who hold the resource-based view posit that unique resources and capabilities that a firm possesses will drive it to choose a specific entry mode. TCT suggests that firms tend to choose an entry mode that could minimize total transaction costs and inefficiencies associated with entering and operating in a foreign market (Williamson, 1975; Canabal \& White, 2008). Dunning (1980) develops the eclectic theory for analyzing entry mode choice by incorporating different theoretical perspectives. This theory suggests that how market entry modes are selected is affected by ownership-specific factors, location-specific factors and internalization factors (Pan \& Tse, 2000). The choice of entry depends on the nature of the proprietary assets that firms possess and their preentry experience (Chan and Reiner, 2019a), the characteristics of the host country and the transaction costs involved (Tian, 2007).

Many researchers tend to agree on the basic factors that firms will consider when making entry choice selections. However, the rich and diverse theoretical constructs indicate that scholars disagree on how to take those identified factors into account when choosing an entry mode (Tian, 2007). Some theories are only used to explain one specific entry mode, others are able to explain a group of entry modes, and still others investigate why one particular entry mode is better than another. Therefore, no consensus is reached on which theory should be employed to explain a particular form of entry.

Nonetheless, TCT is the most widely used theoretical perspective in entry mode research (Brouthers \& Hennart, 2007), particularly as concluded by Canabal and White (2008) and Shen, Puig and Paul (2017) who reviewed 126 and 207 entry mode studies respectively. TCT proposes that firms select the foreign entry mode that minimizes transaction costs. This theoretical perspective could be traced back to Coase (1973), who argued that the analysis of the structure of economic organization should consider not only production costs but also transaction costs. To maximize efficiency, Williamson (1985) argued that the pattern of industrial structure reflects the minimization of the sum of production and transactions costs. This theoretical position has gained prominence in research (Chan \& Reiner, 2019b; Peltzman, 1991; Whinston, 2003).

The decision to select any of the alternative foreign entry modes is based on the relative costs of the transaction, such as the costs of acquiring and handling information about 
the quality of inputs, the prices, and the suppliers. For any contractual arrangement, transaction costs include costs to be borne in the process of negotiating, writing, monitoring, and enforcing contracts. TCT covers the scope of entering a contractual arrangement, operating and controlling the system (Brouthers, Brouthers, \& Werner, 2003). Three broad types of transaction costs to be analyzed in this study are searching, negotiation and enforcement costs.

These costs will have a strong influence on a firm's future survival and performance in the host country (Brouther \& Brouthers, 2000; Morschett, Schramm-Klein, \& Swoboda, 2010). Therefore, TCT has been viewed as an effective way to assess and select foreign entry mode (Brouthers, Brouthers, \& Werner, 2003).

Existing entry mode studies commonly investigate transaction costs from four dimensions, i.e. asset specificity, uncertainty (both internal-behavior and external environment) and frequency of transaction. These dimensions were developed in Williamson's (1985) early research on TCT and have been widely discussed by many entry mode researchers. This case analysis will examine the effects of these dimensions on the decision of selecting CBEC as the preferable entry mode.

Among these dimensions, asset specificity is regarded as one of the most important dimensions due to opportunism (Mroczek, 2014). Scholars studying entry mode choice have proposed that when a greater specificity of assets is required, transaction costs created by potential opportunism will be higher (Brouthers \& Brouthers, 2003). Therefore, most entry mode literature uses asset specificity to explain the choice of internalizing transactions such as changing a joint venture to a wholly owned subsidiary.

Uncertainty is another critical attribute of TCT that influences entry mode selection (Brouthers, Brouthers, \& Werner, 2003; Mroczek, 2014). Researchers also identify interaction between two attributes, namely, economic uncertainty and asset specificity, where transaction costs jump as asset specificity increases due to growing economic uncertainty (Brouthers, Brouthers, \& Werner, 2003).

Frequency is often identified as the rate of occurrence of repetitive exchange (Duan, 2007). Considering this attribute jointly with asset specificity will provide a broader understanding on this subject, that is, more transactions can be translated into a higher possibility of investing in more unrecoverable assets abroad (Mroczek, 2014).

Although TCT has become a dominant theoretical framework for explaining foreign market entry modes (Schellenberg et al., 2018), it has also come under criticism for not being applied broadly. For instance, Lacity and Willcocks (1995) argue that the definition of transaction costs attributes is too vague, which makes the theory difficult to apply. In addition, scholars doubt the possibility of clearly defining the unit of analysis - the transactions, which may overlook the broader historical context for making entry mode decision. Taylor, Zou and Osland (1998) point out that the TCT approach has proven to be more successful in describing choice among the general modes than in describing the specific choice within a general category (e.g. majority stake joint venture vs 50/50 joint venture).

In summary, TCT has two key underlying assumptions, i.e. relevant actors' behavior within a bounded rationality and that the actors could also behave opportunistically (Seggie, 2012). This research will adopt the four key dimensions of TCT: asset 
specificity, environmental uncertainty, behavioral uncertainty, and transaction frequency, which is to be the basic analytical framework.

\subsection{Trust}

Although TCT has become a dominant theoretical framework for explaining foreign market entry modes (Schellenberg et al., 2018), it has also come under criticism for its failing to be applied more broadly. For instance, Lacity and Willcocks (1995) argue that the definition of transaction costs attributes is too vague, which makes the theory difficult to apply. In addition, scholars doubt the possibility of clearly defining the unit of analysis - the transactions, which may overlook the broader historical context for making entry mode decision. Taylor, Zou, and Osland (1998) point out that TCT approach has proven to be more successful in describing choice among the general modes than in describing the specific choice within a general category (e.g. majority stake joint venture vs 50/50 joint venture).

In addition, traditional entry mode studies have tried to focus on investigating the impact of asset specificity, uncertainty and frequency of the transaction and therefore overlook other possible factors that could raise or lower cost. Trust could be one of these factors and later scholars begin seeing trust as a parameter that influences the cost of organizing transactions (Mumdziev \& Windsperger, 2013).

Trust is defined as the expectation that a business partner is honest and reliable. both parties will honor any commitments made rather than behave opportunistically even when an opportunity is available (Mayer et al. ,1995; Geyskens, Steenkamp, \& Kumar, 1998, Holtgrave \& Onay, 2017). Trust can reduce the hazard of opportunism and thus the need for formal governance modes (Bradach \& Eccles, 1989). In analyzing equity and non-equity mode choices, Gulati (1995) indicated that as long as firms build trust with their partners, they would prefer to choose structures with less control.

Brouthers and Brouthers (2003) suggest that trust should be included in market entry mode studies and they believe that relying on trust is one way to reduce entry costs, as trustworthy behaviors can reduce monitoring and control costs. Hoffmann et al. (2010) in their entry mode research also find that the opportunism-mitigating effect of trust lowers costs. As scholars argue, trust can effectively reduce negotiation costs: it helps prevent potential disputes between organizations.

Moreover, recent research suggests that trust is likely to be beneficial when uncertainties hang over the market that businesses operate in. In an uncertain environment, firms need to react quickly and adapt to external changes, and trust built between partners involved in economic exchanges helps them to do that and achieve closer collaboration (Holtgrave \& Onay, 2017).

Den Butter and Mosch (2003) point out that "trust problems are a source of trade barriers and costs. More trust means few trade barriers and less transaction costs." Therefore, they suggest government agencies that promote trade should make efforts to mitigate costs resulting from trust issues. In addition, relevant policies should be introduced to regulate how international legal disputes can be better addressed, encourage reputation building, and enhance traders' knowledge about other cultures. Moreover, they stress that special attention should be paid to the development of information and communication technologies (ICT). Globalization and the burgeoning of ICT contribute to fewer tariffs, lower transport and communication costs, hence 
booming cross-border trade. But this also tends to reduce trust, as cross-border transactions become less transparent when made over the internet.

\subsection{Defining Cross Border E-Commerce}

Cross border e-commerce (CBEC) is an emerging pattern of cross-border trade following the rise of e-commerce (Xue, $\mathrm{Li}, \& \mathrm{Pei}, 2016$ ). There are several different models of CBEC, including B2B, B2C, C2C and B2B2C. Wang et al. (2015) identified several characteristics of CBEC suggesting it needs fewer distributors than traditional exports, and that transactions in CBEC are usually small in volume but higher in the frequency.

According to a report by BCG (Biggs et al., 2017), "China has more e-commerce activity than any county in the world today, and statistics show that Chinese consumers spent $\$ 750$ billion online in 2016 - larger than the combination of the US and the UK." The Chinese e-commerce industry has continuously put forward creative solutions to meet the considerable needs of Chinese consumers (Biggs et al., 2017). The phenomenal rise of online-to-offline (020), social commerce and mobile e-commerce has already shown how active and innovative the Chinese e-commerce market is (Biggs et al., 2017). CBEC has now become another hot trend for Chinese e-commerce players, and as a new market access channel attracting the attention of worldwide brands and retailers (Chan et al., 2016). It should be considered as an alternative market entry mode for brands seeking initial market entry in China (He, 2017).

Academic literature on CBEC is still in its infancy and lacks in-depth coverage. Some studies have looked into specific elements such as designing CBEC logistics (Gessner \& Snodgrass, 2015), taxation implementation (Azam, 2012), and CBEC-related dispute resolution (Cortés \& de la Rosa, 2013; Rule, Rogers, \& del Duca, 2010). Little research exists looking into the challenges and reasons for the rise of this new market access channel and why foreign brands select this new mode of entry and the challenges they face. There is still limited knowledge about the roles of CBEC in the e-commerce ecosystem, particularly in the Chinese context.

China is not only a leader in e-commerce but, as a very large economy with a huge population, it presents significant opportunities for foreign firms using CBEC as an entry mode. The lack of in-depth studies in a Chinese context necessitates urgent research to build relevant knowledge and practical solutions that can be deployed by firms globally for their CBEC initiatives.

\section{Three developmental stages of CBEC in China}

The development of CBEC in China has gone through three main stages. In the early stage (1997-2007), several B2B platforms were created, mainly to help Chinese Small and Medium Enterprises (SMEs) export their products. Alibaba.com and Made-inChina.com were the major platforms then. In the second development stage (20082013), with growing Internet penetration and ever improving cross-border payment and logistics, China's cross-border e-commerce retail export business for overseas consumers (B2C/C2C) flourished. Since 2014, Chinese CBEC B2C has grown rapidly, with the emergence of CBEC B2C platforms and businesses, such as TMall International, JD Worldwide, and NetEase Kaola (AliResearch, 2016). Among these platforms, NetEase Kaola leads the market with a total market share of 24.2\%, TMall International ranked second with a market share of $20.3 \%$, followed by JD Worldwide with $12.5 \%$. 
The remaining market shares were owned by smaller and niche market CBEC platforms (iiMedia Research, 2017). However, the achievements of the B2C, rely on the B2B partnership (see below).

\subsection{Intermediaries, Information and Communication Technology and Transaction Costs}

Peng and Ilinitch (1998) stressed that intermediaries perform a vital function of linking individuals and organizations that would otherwise not be connected. Intermediaries are even more important in international trade as buyers and sellers are often geographically and culturally separated from each other. Scholars claim that the advanced use of ICT has limited the role of traditional intermediaries (Malone, 1987) and made international trade via IT-mediated e-intermediaries possible, rather than only relying on traditional export channels. This can be witnessed by the evolution of the supply chains of traditional exports and those of CBEC. Figure 1 presents the supply chain of a traditional export, illustrated by Wang et al. (2015), when customers could only buy products via a long supply chain involving multiple intermediaries, including exporter, importer, distributor, and retailer. In contrast, in a B2C (Businessto-Customer) cross-border e-commerce, the CBEC platform is the only middleman between foreign firms and customer, as shown in Figure 2. In addition, unlike the traditional intermediaries that serve as middlemen, the e-intermediary for international trade acts as an e-marketplace, connecting worldwide buyers and sellers (Clacks \& Lee, 1999), establishing trade policies and rules and fostering trust among market participants (Chrusciel, 2000).

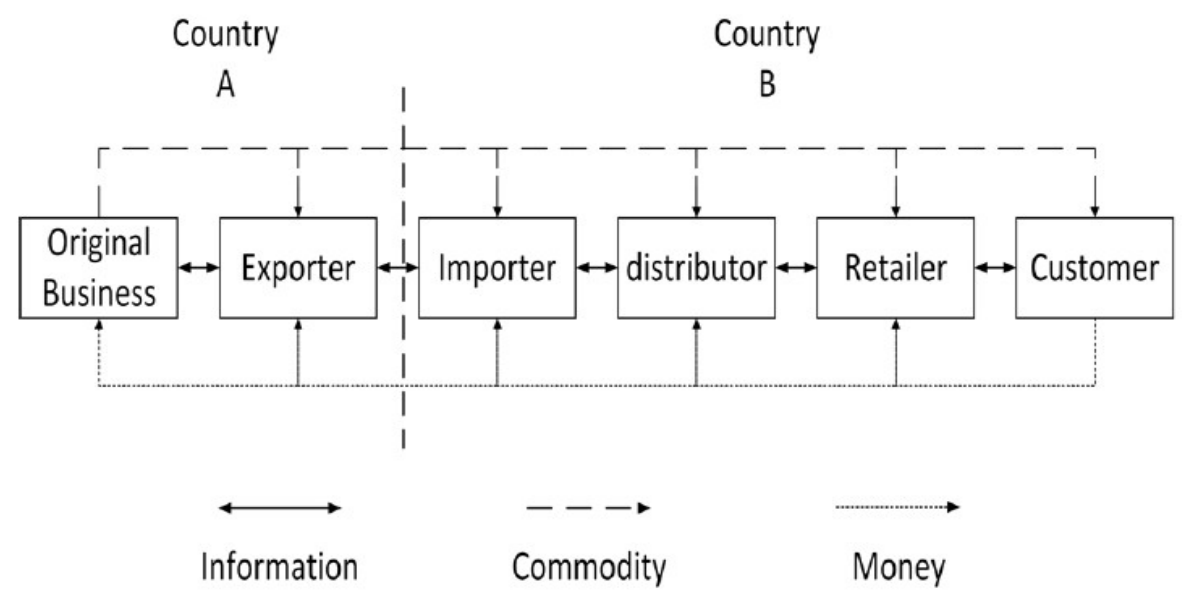

Figure 1: A Typical Supply Chain of Traditional Exporting Mode

Source: Adapted from Wang et al. (2015) 


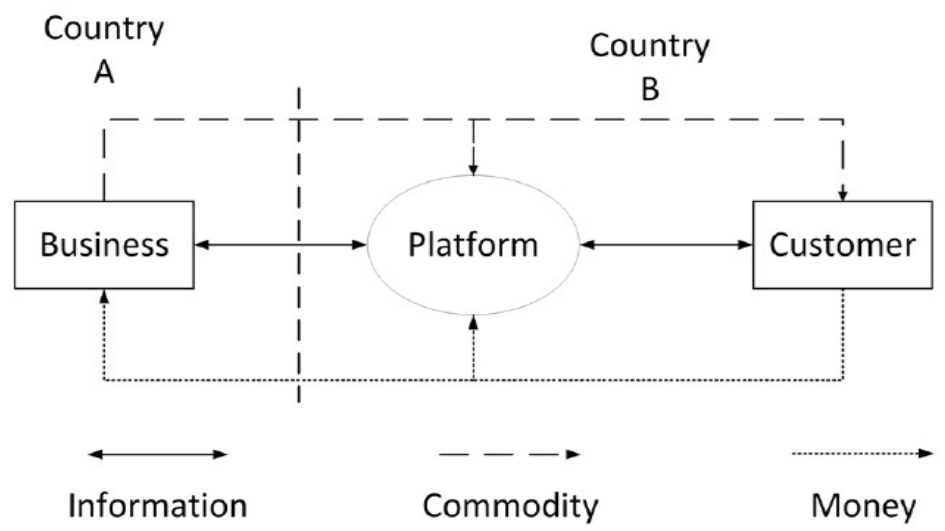

Figure 2: A Supply Chain of CBEC (B2B2C)

Source: Adapted from Wang et al. (2015).

Scholars also point out that ICT could have an impact on transaction costs incurred in international trade in several ways. Firms often face substantial searching costs to obtain and process information on potential customers (Cho \& Tansuhaj, 2013). The introduction of ICT increases available information and increase the speed of information collection and processing, reducing search costs (Ciborra, 1993; Goldsby \& Eckert, 2003). Cordella (2006), however, argues that previous claims about ICT reducing transaction costs only assess the impact of ICT on a single transactional problem rather than overlapping impacts of the aforementioned attributes on transaction costs. Therefore, he addressed that "lower cost can only be achieved when the costs associated with ICT adoption do not exceed the cost of the externalities that are affected by this adoption."

Extant international trade intermediaries' literature mainly focuses on the exporting intermediaries (Peng \& Ilinitch, 1998). Currently, few contributions have been made to identify the function of importing-based intermediaries in the international trade, for instance the TP and the marketplace platform, let alone the CBEC trading platforms as a new type of e-intermediary and other CBEC service providers in the host country. Therefore, it is necessary to explore what kinds of role the new intermediaries play and whether they will influence transaction costs.

\section{Research Methodology}

\subsection{Research Approach}

Over past decades, scholars have explored what prompts firms to choose a particular way of operating in a foreign market. Many studies in the field of industrial organization and international business have adopted quantitative approaches and model building. The seminal work by Anderson and Gatignon (1986) laid the foundation for model testing of the efficiency of foreign entry modes underpinned by TCT analysis.

However, Shaver (2013) in his article of "Do we need more entry mode study?" questioned scholars' enthusiasm for using statistical approaches to examine new factors for entry mode choices. He offers a critique on regression-based research that "chasing $R^{2}$ is a never-ending task" because we can always identify something new for our explanations and advocates a more holistic research approach. Inspired by Shaver's criticism but without discounting the value of some rigorous quantitative 
research methods, this paper focuses on gaining an in-depth understanding of existing phenomena by doing a case study through qualitative analysis.

To understand the rise of cross-border e-commerce platform as a mode for foreign brands to enter the Chinese market, a detailed case study was undertaken, instead of a large-scale survey. Yin (1994) suggests that case studies can address questions like "how" or "why" a phenomenon has emerged and investigate a complex phenomenon in a real-life context (Yin, 1994, p8), providing rich qualitative information. This is also appropriate and effective when examining relatively new phenomena. Therefore, it is appropriate to adopt this approach when studying why cross-border e-commerce has become a much sought-after platform for foreign firms doing business in China.

\subsection{Case Selection}

Case selection is an important consideration in this study. The reasons for justifying single-case studies include the intention to study a critical case, an extreme case, a representative case, a revelatory case (particularly for relatively new phenomenon), or a longitudinal case (Yin, 1994). This study deploys a novel nested case strategy, that is, a case within a case. Firstly, we select a TP who deals with multiple foreign brand owners to facilitate their entrance to Chinese markets using the CBEC mode. Secondly, we select a foreign brand (BETA) which newly entered China using the services of the selected TP. We provide rationales for these strategies in the paragraphs below.

It is difficult to contact a foreign brand directly, especially when it has neither branches nor subsidiaries in China, in addition to potential language and cultural barriers. Meanwhile, studying Chinese CBEC marketplace platforms is also not an ideal choice, because currently most of the Chinese CBEC marketplace platforms only focus on how their own platforms are run, rather than providing operation services for individual flagship e-stores. Therefore, to a large extent, the platform itself is unfamiliar with foreign brands, their entry process, motivations, and the challenges of their daily operation of their e-stores.

Therefore, this research investigates the perspective of a TP and one of its clients - a foreign brand owner, which entered the Chinese market using the CBEC mode. TP is a key enabling actor in this entry mode. Based in the host country, TP in China establishes a B2B relationship with foreign firms, assisting their entry to the Chinese market and successfully internationalizes their efforts in the e-commerce era. An established TP could possibly work with a high number of foreign firms on their CBEC strategies in China, and thereby could provide valuable insights for answering the research question.

With the above considerations, the authors first approached TP-E, an anonymized third-party e-commerce TP in China. TP-E has direct knowledge of both foreign brands and CBEC platforms and is amongst the top five TPs in the Chinese CBEC market. The other similar size competitor is Baozun, which listed on NASDAQ in 2015. Baozun works exclusively for TMall and manages over 100 major foreign brands in China. Alibaba, the owner of TMall, also has a substantial stake in Baozun.

TP-E establishes a B2B relationship to link the foreign brand owner with Chinese marketplace platforms. It also helps foreign brands perform smoothly on Chinese CBEC platforms. It helps the initial decision on which platform(s) to host their flagship stores, the customization of their digital marketing solutions, and the international logistics and supply chain solutions, and everyday operations of the flagship store. TP-E has 
dealt with various foreign brands since its inception in 2013, including many foreign Fortune 500 companies, and also some small and medium firms. TP-E claims that it processed over USD750 million worth of sales in China in 2017. JingDong, one of the two biggest marketplace platforms owners, has also invested and holds a substantial stake in TP-E.

Secondly, the authors selected a foreign brand that Chinese customers had little knowledge about - it represents the early entry of a brand to this new market. After reviewing several clients' archives on TP-E, the authors selected BETA as a nested purposeful case in accordance with the case selection method proposed by Yin (1994). This decision aims to provide insightful and rich information about a new phenomenon. BETA is a Japanese skincare brand owned by Alpha-BETA Group, which focuses on beauty and health products, with cosmetics at its core. TP-E advised BETA to operate on JD Worldwide, one of the top CBEC platforms in China. BETA had had a history of failed experiences in Chinese market entry, providing another dimension to this study, further elaborated later in Section 4.

After several rounds of negotiations with both TP-E and JD, BETA decided to open its flagship e-store on JD Worldwide and began to sell its beauty products to Chinese customers on this platform, re-entering the Chinese market via CBEC. It is therefore a very good candidate for this study.

\subsection{Data Collection and Analysis}

This research collected both primary and secondary data related to the "BETA project". Secondary information was mainly gained from industrial reports, TP-E's internal documents, the official website of BETA, and news articles from various media outlets. Primary data were collected mainly through interviews, conducted in the Chinese. Interviewees possessed knowledge on the Chinese cross-border e-commerce market and were familiar with the BETA project. They included TP-E's founder, its Chief Operating Officer, the project manager, the marketing staff, and the operation staff, as they all possess considerable experience of the Chinese CEBC Market. Table 1 presents some key information about these interviewees. A series of semi-structured interviews, each lasting 30-60 minutes, were conducted through video calls. With the consent of the interviewees, audio records were taken and then transcribed for data interpretation and future reference. The results of the analysis were translated to English and cross-checked by another co-author.

Table 1: Information about the Interviewees

\begin{tabular}{|l|l|l|}
\hline Respondent & Position & Experience \\
\hline Respondent A & $\begin{array}{l}\text { Co-founder of } \\
\text { TP-E (CEO) }\end{array}$ & $\begin{array}{l}\text { First mover in the Chinese CBEC market since 2013; in-depth } \\
\text { understanding of the Chinese CBEC market and different } \\
\text { CBEC platforms; in charge of the overall management of TP-E }\end{array}$ \\
\hline Respondent B & $\begin{array}{l}\text { Chief Operation } \\
\text { Officer (COO) }\end{array}$ & $\begin{array}{l}\text { In charge of daily operations of TP-E, such as communication } \\
\text { with CBEC platforms, foreign brands and other digital } \\
\text { marketing channels. Experienced in platform operations }\end{array}$ \\
\hline Respondent C & Project manager & $\begin{array}{l}\text { Overall management of the Alpha-BETA Commerce project, } \\
\text { has led several successful foreign brand entry cases }\end{array}$ \\
\hline Respondent D & $\begin{array}{l}\text { Project operation } \\
\text { staff }\end{array}$ & $\begin{array}{l}\text { Responsible for initiating market campaign plans, budgeting } \\
\text { and communication }\end{array}$ \\
\hline Respondent E & $\begin{array}{l}\text { Pesponsible for improving and implementing the marketing } \\
\text { marketing staff } \\
\text { plans }\end{array}$ \\
\hline
\end{tabular}




\begin{tabular}{|l|l|l|}
\hline Respondent F & $\begin{array}{l}\text { Business } \\
\text { Development } \\
\text { Manager }\end{array}$ & Responsible for developing business and channel \\
\hline Respondent G & Operation Staff & $\begin{array}{l}\text { Responsible for maintaining online products, and tracking } \\
\text { the order status }\end{array}$ \\
\hline Respondent H & Operation Staff & Responsible for cooperation with a major American retailer. \\
\hline Respondent I & Marketing Staff & $\begin{array}{l}\text { Responsible for marketing, editing photos and videos for } \\
\text { products }\end{array}$ \\
\hline Respondent J & Operation Staff & $\begin{array}{l}\text { Responsible for home appliances, mainly from two major } \\
\text { German manufacturers }\end{array}$ \\
\hline
\end{tabular}

This is a case study and therefore the data analysis consisted of examining, categorizing, tabulating, and testing as well as involving the recombination of empirical evidence to draw conclusions, as recommended by Yin (1994). The authors drew from multiple sources of data including interviews of multiple respondents, original company documents and websites (See Table 2). This also provides a way to triangulate data and information to enhance the reliability of this research.

The data analysis process was guided by prior theory of foreign market entry mode, particularly on transaction cost theory (four dimensions: asset specificity, environmental uncertainty, behavioral uncertainty and transaction frequency) and an additional dimension of trust, as discussed in the literature review. This forms the basis framework for the analysis and discussion in Section 4.

\section{Table 2: Key Case Documents Consulted}

\begin{tabular}{|l|}
\hline TP-E, 2017. TP-E Business Plan \\
\hline TP-E, 2016a. Cosmetics online market research (for BETA). \\
\hline TP-E, 2016b. Operation Plan for BETA \\
\hline TP-E, 2016c. BETA JD Flagship e-store performance report (June 2016-November 2016). \\
\hline TP-E, 2016d. Alpha-BETA JD Flagship e-Store Opening Proposal. \\
\hline
\end{tabular}

Source: Internally generated by TP-E BETA project team and with permission obtained from BETA

\section{Research Findings and Discussions \\ 4.1 Case Firm}

As described in Section 3.2, BETA is a Japanese skincare brand that positions itself as a retailer mainly in the mainstream offline market in Japan. It ventured into the Chinese market, before adopting CBEC, by setting up various physical stores but were unable to survive the competition. Its marketing and branding strategy are explained by Respondent B succinctly:

"In Japan, BETA sells its product offline, mainly in supermarkets, department stores and specialty stores. Actually, it is not the first time for BETA to enter into Chinese market ... by opening several physical stores. However, due to unsatisfactory performance, BETA quit its offline market in China. As for the positioning, this brand chooses the customer-friendly direction-each SKU's price is below RMB 300. Its main customers are women aged 25 to 40 ... skin care product... The functionality of its product is not that strong, and mainly focuses on moisture retention."

Given the disappointing experience it had had in the Chinese market, it was not easy for BETA to start CBEC in China. Moreover, being a small brand, it had little recognition 
in the Chinese market making it even harder for it to enter the Chinese market on its own. To avoid a repeat of failed entry, BETA needed an intermediary that could help in its re-launch and TP-E provided a needed platform for that. The situation was explained by Respondent E:

"It is extremely difficult for small foreign brands like BETA, to obtain brand recognition and attract new customers to their own e-shopping website in a short time. The process is always time-consuming and costly. Even though the parent company - Alpha - is recognized among Chinese consumers, BETA, as a small brand belonging to the big brand, has no brand recognition in China, therefore, it needs TP-E's help. TP-E can help BETA to better understand consumer psychology and habits, to know how to introduce this brand to them, such as using the current popular content marketing."

\subsection{Challenges faced by BETA in entering China \\ 4.2.1 Chinese Customer Purchasing Behaviors}

A growing number of Chinese consumers demands premium products. Consumer behavior is transforming from one of being price sensitive to quality sensitive (Walters et al., 2017). Respondent E, who is responsible for the integrated marketing of BETA, expressed her opinion on Chinese consumers:

"Chinese consumers are 'the most' difficult consumer to deal with and can be regarded as one of the biggest challenges that foreign brands will meet. For example, consumers in tier-one cities could be different from consumers in the second, third and even forth-tier cities. Age also matters. For instance, the newly rising consumer group, "post 1990s" (the young generation born in the 1990s), was born in the information era and relies more on the Internet and electronic devices and therefore, could gain greater access to information about foreign brands and foreign products. That is the reason the demand for foreign highquality products is higher among this group of young people."

The above highlights changes in consumption patterns, which generate opportunities but pose challenges for foreign brands, such as BETA, in their venture into the Chinese market.

Chinese consumers have become smarter compared to decades ago when internet coverage and access to information was limited. They have formed their distinctive consumption consciousness and habits via e-commence (Walters et al., 2011). Consumers in countries such as the UK and US, are still approached by traditional sales methods, such as telemarketing, catalogue sales and TV advertising. However, Chinese customers are becoming less interested in these traditional sales methods. Most importantly, unlike consumers in many other countries, Chinese online shoppers seldom browse and purchase products from brand owners' websites (Walters et al., 2017). They actively collect product information via other channels, e.g. by searching keywords on social media platforms, such as WeChat and Weibo; visiting e-commerce platforms, such as TMall and JD; looking through product recommendation blogs; and watching videos produced by KOLs.

Another point highlighted by the respondents (as mentioned in the quote above) is that foreign brands, especially those which have no branches and subsidiaries in China and are unfamiliar with Chinese consumers, may fail to understand what kinds of customers they will serve and how difficult it is to satisfy them. The Chinese retail 
market is complex and understanding Chinese consumers is a key factor for foreign firms that seek to grow and prosper in the market (Respondent $\mathrm{H}$ ).

\subsubsection{Uncertainties and Opportunistic Behaviors}

The Chinese retail market is a highly dynamic one entailing uncertainties in at least three aspects: (1) unpredictable consumer demand, (2) intense brand competition in the retail market, and (3) changing government policies and regulations. Chinese consumers are highly segmented. Different groups of consumers may have totally distinctive shopping preferences and habits. Respondent A noted the uncertainties present in the Chinese CBEC environment as:

"We are facing all kinds of uncertainties ... all things related to launching and marketing foreign brands are highly uncertain. In terms of marketing, foreign brands must consider the following: which particular channel is the most effective, which channel strategy to adopt, and how to allocate and combine different channels. In addition, the channel allocation also varies in accordance with the different phases of entering the market. To a large extent, foreign brands have no idea about these issues. Secondly, foreign brands are unfamiliar with Chinese consumers ... The Chinese market is a vast market that has a high demand on the ability to launch the business and operate efficiently, with an integrated approach to resource allocation."

Chinese consumers have high expectations of what they purchase and spend a lot time shopping. In China, shopping is not only about transactions, but also about entertainment, discovery and social engagement with friends, celebrities and KOLs (Biggs et al., 2017). It is a combination of online and offline experience. The changing patterns of Chinese consumer habits create opportunities but also pose challenges for introducing new products and services. In particular, many foreign brands entering China have insufficient knowledge about customers and their changing consumption habits. They are also disadvantaged due to lack of brand recognition and reputation.

The second aspect of uncertainty comes from the intense brand competition in the retail market. To stay one step ahead of the competition, existing players constantly offer innovative products, and create new channels to engage customers. For example, recently, many cosmetics brands engaged Internet makeup KOLs on live streaming platforms to share their views on how they felt after using their products.

Lack of knowledge of the products and the marketing strategies of existing players in the Chinese retail market poses another challenge for foreign brands. The practices and complexity of using multimedia and multichannel to reach and engage Chinese consumers is underestimated by many foreign brands.

The third aspect of uncertainties comes from changing government policies and regulations. In response to sluggish economic growth, China has initiated several measures to stimulate the economy. For example, the Belt and Road Initiative is proposed to help diffuse surplus capacity through overseas markets. Hence, the government encourages Chinese businesses to export and make direct foreign investments. Complementary policies and regulations have also been issued, such as policies on promoting cross-border import e-commerce. Even though the substantial exemption on relevant tariffs and VAT can be regarded as an indicator of the Chinese government's favorable attitude towards CBEC, public information may not be sufficient for foreign brands to interpret those regulations in a timely manner. 
Respondent A pointed to the favorable policy benefits for BETA to use CBEC as the entry mode in Chinese market:

"Taxation for the import of general trade is usually higher than the taxation for cross-border e-commerce."

"CBEC import is regulated by each single package. Therefore, the customs clearance time is shortened, with the quickest clearance taking about four hours. Another aspect is about tax deduction and exemption. More importantly, the government gives permission for the exemption of pre-approved goods for some selected industries, such as healthcare products and cosmetics. Therefore, in these sectors, CBEC seems to be the entry mode with the lowest cost. As such, many foreign brands choose this mode to enter into Chinese market."

In addition, Respondent I also warned about pending changes in taxation regulations, which could have significant implications for CBEC. This is similar in other global markets where taxation regulations on e-commerce are still developing (Azam, 2012).

"It is said the new e-commerce policy will be announced in the beginning of 2019. How the market will be influenced in the future? We need to keep an eye on it."

The three uncertainties analyzed above can contribute to increased transaction costs for many foreign firms entering China. Firstly, search costs, as a component of transaction costs, will be incurred in order to fully understand Chinese consumers and the retail markets in China. These search costs include the costs for the following activities: conducting consumer research to understand the complex consumer demands; analyzing data on both online and offline cosmetics markets; studying the practices of multichannel marketing; and analyzing which groups of customers to target, which products to introduce, and which marketing channels to select. Substantial investments would also be required to build up their brand awareness and recognition. If a foreign firm such as BETA adopts CBEC, these search costs listed above would generally be covered by the TP services.

To obtain the results mentioned above, intensive negotiation costs will occur. As BETA has little knowledge about the Chinese market, it may also find it difficult to seek out the right market research companies, especially those that are familiar with the cosmetics industry. Negotiations will also happen every time when BETA attempts to find a new partner for selling and marketing. For example, BETA should negotiate with shopping malls, department stores, e-commerce platforms, marketing firms, consulting firms, logistics firms and even payment firms. These costs include not only the costs of conducting international negotiations, but also costs of preventing and solving risks when dealing with unfamiliar foreign negotiators.

Since BETA is a small Japanese brand, it is possible that it does not have strong bargaining power to create an advantageous position during negotiations. Moreover, cultural and language barriers will make the negotiation process time-consuming and costly. Enforcement costs are also needed to enforce the fulfilment of contractual obligations. Given there are so many trade partners involved in international trade; it is impossible for BETA to control all partners not to behave opportunistically.

BETA would substantially reduce searching, negotiation and enforcement costs via CBEC entry mode, cooperating with a CBEC platform and a CBEC technology provider. In this case study, both the JD marketplace platform and TP-E have accumulated substantial market data and data analysis capabilities. From a case document (TP-E, 
2016a), the authors learnt that TP-E has done a lot of work on studying the online cosmetic market. The research delivered to BETA includes performance and market share of other foreign competitors, broken down by category (e.g. face cleaning, mask, shampoo, oral care) and on each major e-commerce platform (e.g. TMall, JD, Yihaodian, Amazon). This market analysis could help TP-E to advise BETA on which products to introduce on which e-commerce platform.

Moreover, JD platform and TP-E have their own resources and networks, as well as a high brand awareness in the e-commerce marketplace, thereby enabling them to have a stronger negotiation power when dealing with various marketing channels on behalf of BETA. The entire market entry process is therefore simplified by CBEC mode, saving time and resources for foreign firms entering the Chinese market in comparison with other traditional choices of entry mode. In addition, CBEC is exempted from many regulatory requirements such as the required pre-approval for any foreign direct investment, a process that often takes a month or longer.

\subsubsection{Lower Asset Specificity in High Transaction Frequency}

Asset specificity is one of the key determinants of TCT. Operating an overseas establishment, under an equity-based entry mode, would require a high level of investment in human and physical assets, including investment in recruiting talent specializing in the Chinese market and the relevant sector. Other types of investment are also required, e.g. establishing payment systems, logistic systems, and warehouses. All these investments specific to the entry mode might create a lock-in condition favorable to the relevant transaction partners. This will entice them to behave opportunistically, especially in an overseas market with a high level of uncertainty. In accordance with TCT, a high level of asset specificity is associated with high transaction costs (Kabadayi, 2011). Hence, these will lead to a decision to avoid an equity-based entry mode.

In contrast, CBEC offers an attractive alternative to avoid increasing transaction costs due to high level of asset specificity. Firstly, the cost for engaging intermediaries (TP) is not high in views of the nature of BETA's products, which are not technology intensive. BETA only needs a TP with marketing expertise to manage its not so highly differentiated products. There will be some costs for setting up an e-shop, but investment is expected to be much lower than physical store. A case document (TP-E, 2016b) shows that TP-E appointed four experienced specialists for BETA project, mainly responsible for negotiation with JD platform and BETA, and for the planning and implementation of sales and marketing campaigns (as in Table 1).

Another key dimension to consider is Transaction frequency (the rate of occurrences of repetitive transactions) is expected to be higher in e-commerce, compared with the traditional commodity exports. Transactions are measured by individual parcels in cross-border e-commerce rather than traditional bulk export. Thereby, high transaction frequency will multiply the effects of high transaction costs. In addition, TCT scholars have argued that the higher repeatability of the transaction will increase the tendency of investing more in unrecoverable assets in the host country and therefore increasing asset specificity of the foreign operations.

Nonetheless, despite the high transaction frequency, CBEC offers some advantages. There is no necessity for BETA to invest in any additional assets, such as logistics and warehouses. All those investments have been transferred to CBEC marketplace 
platforms, in this case, JD. The only costs borne by BETA are the operation costs charged by JD and TP-E. Fees and commissions charged by technology intermediaries are expected to be less than the costs of asset investments.

Moreover, a mature ecosystem has already been established for CBEC in China. A comprehensive ecosystem can improve the quality of information flow (knowledge about the Chinese market) and decrease the need for adopting high control modes. Moreover, the established healthy ecosystem can also represent an effective mechanism for reducing uncertainties and therefore suppressing opportunistic behaviors and making costly investment in specific assets less necessary (Maekelburger, Schwens, \& Kabst, 2012), particularly for small brands like BETA.

\subsubsection{Effects Technology Providers and Marketplace Platform on Trust}

Mutual trust is a common issue in international trade and the lack of trust is also regarded as a key source of increasing transaction costs. Transactional issues such as quality and disputes have been among key concerns for both buyers and sellers (Rule et al., 2010). It is equally true for online trade (Schmitz, 2016). In a new foreign market entry, trust is to be established between the firm and its new business partners. For a small and relatively unknown brand like BETA, the level of customer trust can be improved by adopting traditional entry modes with a high-level of control, e.g. wholly owned subsidiary with the presence of physical stores. But this mode will not only incur substantial investment in resource and time, but also require some efforts to build trust among its many partners in order to mitigate opportunistic behavior, which leads to high transaction costs. If BETA resort to export as an entry mode, with a lower level of control, the issues of trust could be more apparent. Substantial investment might be required to build trust among its marketing channels.

In spite of the above challenges, CBEC mode provides a preferable option over other entry modes with a high level of control, e.g. equity-based mode. For instance, BETA's decision on CBEC brings two key advantages, i.e. reducing the number of marketing channels and related partners; and enhancing the level of customer's trust. CBEC will help in reducing the investment in building trust, as the number of business parties reduces, and the transaction data is more transparent. BETA only needs to deal directly with TP-E and indirectly with JD - the platform operator.

By collaborating with an established e-commerce platform, BETA can also increase the level of trust the consumers have on its products and operation, further reducing the transaction costs when dealing with various requests from individual customer. Over the years, CBEC platforms have gained the trust of the consumers, and this can be used as to endorse BETA so that it can gain brand impact and customer trust. For example, JD's approach to ensuring "no fake products" by imposing a stringent certification procedure to authenticate a flagship e-store could mitigate consumers' concerns over counterfeit products. Moreover, JD's payment and logistics systems and after-sales services provide further guarantees for BETA, dispelling consumer's concerns about BETA's e-store and delivery. Respondent B and Respondent D explained the element of trust:

"Listing on JD can be seen as gaining the access to a high level of customer traffic since JD has already accumulated a vast number of loyal users ... If BETA just sets up a new Chinese version of its official website, several obstacles need to be overcome before products are sold ... On JD Worldwide.com, the BETA name can 
be shown on 'most searched', floating advertisements can be displayed, and product information can also be recommended on the "Today's Recommendation" box - a feature that makes personalized recommendations to its shoppers. Moreover, JD would also introduce BETA in their daily newsletter and daily focus blogs. All these methods are aimed at allowing BETA to access to more consumers."

"JD has other resources available to BETA such as e-payment and logistics. BETA's products are firstly delivered to JD's warehouses located in China's tariff-free zones. After the platform receives orders, goods will be delivered to the customers' addresses. From overseas warehouses to the 'last mile of delivery', customers can receive their parcels within 7 days via JD's highly integrated supply chain. Moreover, JD Worldwide provides an e-payment system for foreign brands and customers. Customers can make payments via the 'ID wallet', without the requirement for an international credit card."

The above quotation points to the value-added benefits of using CBEC. Compared with other market entry choices, the selection of CBEC by BETA can firstly reduce the cost of searching for potential consumers, as a higher level of trust will attract more consumers. Moreover, trust can effectively reduce negotiation costs, as customers have already built trust on the flagship e-store. Both parties may spend less effort and time negotiating the specific terms and conditions of purchase. BETA builds on and gains the advantage of the trustworthy relationship between the consumers and the marketplace platform. The technology provider (TP-E) helps BETA to capitalize on these key elements to reduce its transaction costs.

\section{Discussion and Conclusions}

This paper examines the complex motivations for foreign firms to select cross-border e-commerce as their market entry mode. The research has reviewed the literature on foreign market entry mode decisions, the roles of intermediaries, ICT and, particularly based on transaction cost theory, the theoretical foundations identified for this study. A case study approach based on TCT was adopted to explain the reasons why foreign brands choose CBEC as an entry mode from the TCT, by using an example in China.

From the analysis and discussion in Section 4, it can be concluded that the reasons for the case study firm - BETA, to choose CBEC as its China entry mode may be explained by lower transaction costs associated with this mode. Particularly, transaction costs are particularly reduced by the involvement of specialized technology intermediaries in a mature CBEC ecosystem with favorable government policies. This research concludes that, to a great extent, TCT framework is an applicable approach for explaining foreign firm entry mode selection, particularly the motivation to deploy the CBEC mode. The authors included all four components of Williamson's (1975) TCT: asset specificity, uncertainty, opportunities behavior, and frequency of transaction, offering a logical framework for foreign firms to evaluate their entry mode options and the markets they intend to enter. TCT has been viewed as important theory for the choice of entry mode for a successful foreign market entry, particularly by SMEs (Brouthers \& Nakos, 2004).

In addition to proposing TCT as the key theoretical ground for CBEC selection, the important role of trust on entry mode choice is also acknowledged in this study. The authors drew the conclusion that CBEC is a (transaction) cost-effective way of foreign 
market entry, and an easier way to build trust, particularly for the Chinese market. This is also because CBEC platforms have already established high levels of trust through long-term specific asset investments such as platforms as well as the skills and knowledge of CBEC consulting/technology providers. A transfer of trust to foreign firms (e.g. BETA) could be beneficial to those foreign firms. This finding concurs with Brouthers and Brouthers (2003) that a high level of trust could reduce the cost of entry, particularly in the reduction of monitoring and control costs. Trust is built between the foreign brand and the consumers, via the marketplace platform and the technology provider, to reduce barriers and thereby transaction costs, similar to the proposition by den Butter and Mosch (2003). Furthermore, a closer collaboration between foreign brand and TP-E/JD will reduce negotiation costs and dispute costs, where these findings agree with the position of Hoffmann et al. (2010). It would also enhance collaboration and therefore reduce costs (see Holtgrave \& Onay, 2017).

This study has important implications in the understanding of foreign market entry mode selection in the era of increasing technology use. It has practical implications for managers of foreign firms which plan to enter new markets. The selection criteria on foreign market entry mode should not only include operation costs such as logistics (Gessner \& Snodgrass, 2015) but also take transaction costs into consideration. This research also highlighted the role of technology providers and marketplace platform in reducing the transaction costs of CBEC, where they are also integral parts of the CBEC ecosystem.

This study focuses on the Chinese consumer market but could be valuable in other global marketplaces. It is possible that similar conclusions could also be found about general foreign market entry in other markets where there is a high level of ecommerce. Issues related to trust are very common in other markets (Rule et al, 2010; Schmitz, 2016).

\section{Limitations of this Research}

However, this study has limitations. Firstly, this research studies why "Chinese crossborder e-commerce platforms and third-party e-commerce supporting service providers" are a new form of exporting mode, examples are chosen from the perspective of foreign Small and Medium Enterprises (SMEs). The authors had no chance to collect information directly from the foreign brand due to their inability to speak Japanese and time limitations. This research only used information obtained from one intermediary (the e-commerce technology provider - TP-E). The chances are that the information obtained from the intermediary is not fully objective and complete in explaining this cross-border entry mode choice. But these findings are justifiable as a TP works with many foreign firms who select CBEC to enter China's markets.

Secondly, all the discussion and understanding are based on only one specific case study, therefore, new research agendas that includes larger case-study samples of foreign brands should be developed, and possibly small and medium brands from more countries and different sectors.

Thirdly, it should be noticed that Hill et al. (1990) argued that transaction cost explanations of the choice of entry mode focus on each entry decision in isolation from each other. In practice, a multinational corporation's choice of entry mode may depend on the strategic relationship that MNC envisages of operations in different countries. Thus, a particular entry decision cannot be viewed in isolation. Limiting the framework 
to transaction cost explanations overlooks the role that global strategy and global competition play in determining an appropriate entry mode. But it could be reasonably accepted for SMEs. 


\section{References}

AliResearch (2016). The future of trade: Cross-border e-commerce connects the world. http://i.aliresearch.com/img/20160901/20160901101059.pdf

Anderson, E., \& Gatignon, H. (1986). Modes of foreign entry: A transaction cost analysis and propositions. Journal of International Business Studies, 17(3), 1-26.

Azam, R. (2012). Global taxation of cross-border e-commerce income. Virginia Tax Review, 31(4), 639-693.

Biggs, C., Chande, A., Matthews, E., Mercier, P., Wang, A., \& Zou, L. (2017). What China reveals about the future of shopping. https://www.bcg.com/publications/2017/retail-globalization-china-reveals-futureshopping.aspx

Bradach, J. L., \& Eccles, R. G. (1989). Price, authority, and trust: from ideal types to plural form. Annual Review of Sociology, 15(1), 97-118.

Brouthers, K. D., \& Brouthers, L. E. (2000). Acquisition or greenfield start-up? Institutional, cultural, and transaction cost influences. Strategic Management Journal, 21(1), 89-97.

Brouthers, K. D., \& Brouthers, L. E. (2003). Why service and manufacturing entry mode choices differ: The influence of transaction cost factors, risk and trust. Journal of Management Studies, 40(5), 1179-1204.

Brouthers, K. D., Brouthers, L. E., \& Werner, S. (2003). Research notes and commentaries-Transaction cost-enhanced entry mode choice and firm performance. Strategic Management Journal, 24(12), 1239-1248.

Brouthers, K., \& Nakos, G. (2004). SME entry mode choice and performance: A transaction cost perspective. Entrepreneurship Theory and Practice, 28(3), 229-247.

Brouthers, K. D., \& Hennart, J. F. (2007). Boundaries of the firm: insights from international entry mode research. Journal of Management, 33(3), 395- 425

Buckley, P. J., \& Casson, M. C. (1998). Analyzing foreign market entry strategies: Extending the internalization approach. Journal of International Business Studies, 29(3), 539-561.

Canabal, A., \& White, G. O. (2008). Entry mode research: Past and future. International Business Review, 17(3), 267-284.

Chan, J.H., \& Reiner, D. (2019a). Dominance by birthright"? Reconfiguration of firm boundaries to acquire new resources and capabilities. Industrial Management \& Data Systems, 119 (9), 1888-1907.

Chan, J. H., \& Reiner, D. (2019). Evolution in inter-firm governance along the transport biofuel value chain in Maritime Silk Road countries. Transportation Research Part E: Logistics and Transportation Review, 122, 268-282.

Chan, W., Wouters, I. W., \& Wu, R. (2016). Shopping without boundaries: China crossborder e-commerce, an opportunity not to be missed. http://www.oliverwyman.com/content/dam/oliverwyman/global/en/2016/aug/Sh opping-Without-Boundaries.pdf 
Cho, H., \& Tansuhaj, P. S. (2013). Becoming a global SME: determinants of SMEs' decision to use e-intermediaries in export Marketing. Thunderbird International Business Review, 55(5), 513-530.

Chrusciel, D. (2000). The Internet intermediary: Gateway to Internet commerce opportunities. Journal of Internet Banking and Commerce, 5(1) http://www.icommercecentral.com/

Ciborra, C. U. (1993). Teams markets and systems. Cambridge: Cambridge University Press.

Clarks, T. H., \& Lee, H. G. (1999). Electronic intermediaries: trust building and market differentiation. Proceedings of the 32nd Hawaii International Conference on System Science, USA.

Coase, R. (1937). The nature of the firm. Economica, 4, 386-405.

Cordella, A. (2006). Transaction costs and information systems: does IT add up? Journal of Information Technology, 21(3), 195-202.

Cortés, P., \& de la Rosa, F. (2013). Building a global redress system for low-value crossborder disputes. The International and Comparative Law Quarterly, 62(2), 407-440.

Datta, D. K., Hemnann, P., \& Rasheed, A. A. (2002). Choice of foreign market entry modes: Critical review and future directions. Advances in Comparative International Management, 14, 85-153.

den Butter, F. A. G., \& Mosch, R. H. J. (2003). Trade, trust and transaction costs. Tinbergen Institute Working Paper No. 2003-082/3. https://ssrn.com/abstract $=459501$

Duan, Z. (2007). Analysis of e-commerce model in transaction cost economics framework. Information Sciences, 9, 627-634.

Dunning, J. H. (1980). Toward an eclectic theory of international production: Some empirical tests. Journal of International Business Studies, (Spring/Summer), 9-31.

Forsgren, M. \& Hagström, P. (2007). Ignorant and impatient internationalization? The Uppsala model and internationalization patterns for Internet-related firms. Critical Perspectives on International Business, 3(4), 291-305.

Gatignon, H. \& Anderson, E. (1988). The multinational corporation's degree of control over foreign subsidiaries: An empirical test of a transaction cost explanation. Journal of Law, Economics \& Organization, 4(Fall), 305-336.

Gessner, G. H., \& Snodgrass, C. R. (2015). Designing e-commerce cross-border distribution networks for small and medium-size enterprises incorporating Canadian and U.S. trade incentive programs. Research in Transportation Business \& Management, 16, 84-94.

Geyskens, I., Steenkamp, J-B. E. M., \& Kumar, N. (1998). Generalizations about trust in marketing channel relationships using meta-analysis. International Journal of Research in Marketing, 15(3), 223-248.

Goldsby, T. J., \& Eckert, J. A. (2003). Electronic transportation marketplaces: A transaction cost perspectives. Industrial Marketing Management, 32(3), 187-198. 
Granovetter M. (1985). Economic action and social structure: the problem of embeddedness. American Journal of Sociology, 91(3), 481-510.

Gulati, R. (1995). Does familiarity breed trust? Academy of Management Journal, 38(1), 85-112.

He, W. (2017). Online retail boom hits international shopping numbers. China Daily. http://global.chinadaily.com.cn/a/201707/18/WS59bbf069a310ded8ac18e7d5.html

Hill, C., Hwang, P., \& Kim, W. (1990). An eclectic theory of the choice of international entry mode. Strategic Management Journal, 11(2), 117-128.

Hoffmann, W. H., Neumann, K., \& Speckbacher, G. (2010). The effect of interorganizational trust on make-or-cooperate decisions: Disentangling opportunism-dependent and opportunism-independent effects of trust. European Management Review, 7(2), 101-115.

Holtgrave, M., \& Onay, M. (2017). Success through trust, control, and learning? Contrasting the drivers of SME performance between different modes of foreign market entry. Administrative Sciences, 7(9), 1-24.

iiMedia Research (2017). 2017H1 China importing e-commerce market research report (in Chinese) http://www.iimedia.cn/52896.html

Johnson, J. \& Tellis, G. J. (2008). Drivers of success for market entry into China and India. Journal of Marketing, 72(3), 1-13.

Kabadayi, S. (2011). Choosing the right multiple channel system to minimize transaction costs. Industrial Marketing Management, 40(5), 763-773.

Lacity, M. C., \& Willcocks, L.P. (1995). Interpreting information technology sourcing decisions from a transaction cost perspective: Findings and critique. Accounting, Management and Information Technologies, 5(3-4), 203-244

Liu, X., Chen, D., \& Cai, J. (2015). The operation of the cross-border e-commerce logistics in China. International Journal of Intelligent Information Systems, 4(2-2), 15-18.

Maekelburger, B., Schwens, C., \& Kabst, R. (2012). Asset specificity and foreign market entry mode choice of small and medium-sized enterprises: The moderating influence of knowledge safeguards and institutional safeguards. Journal of International Business Studies, 43(5), 458-476.

Malone, T. (1987). Electronic markets and electronic hierarchies. Communications of the ACM, 30(6), 484-497.

Mayer, R. C., Davis, J. H., \& Schoorman, F. D. (1995). An integrative model of organizational trust. Academy of Management Review, 20(3), 709-734.

McDermott, K., \& Payvision, B. V. (2015). Key business drivers and opportunities in cross-border ecommerce. Payvision, Amsterdam.

Morschett, D., Schramm-Klein, H., \& Swoboda, B. (2010). Decades of research on market entry modes: What do we really know about external antecedents of entry mode choice? Journal of International Management, 16(1), 60-77.

Mroczek, K. (2014). Transaction cost theory-explaining entry mode choices. The Poznan University of Economics Review, 14(1), 48. 
Mumdziev, N., \& Windsperger, J. (2013). An extended transaction cost model of decision rights allocation in franchising: the moderating role of trust. Managerial and Decision Economics, 34(3-5), 170-182.

Nielsen (2017). New Retailer: A new battleground for Chinese e-commerce (in Chinese), http://www.nielsen.com

Pan, Y., \& Tse, D. K. (2000). The hierarchical model of market entry modes. Journal of International Business Studies, 31(4), 535-554.

Peltzman, S. (1991). The handbook of industrial organization: A review article. Journal of Political Economy, 99(1), 201-217.

Peng, M. W., \& Ilinitch, A. Y. (1998). Export intermediary firms: A note on export development research. Journal of International Business Studies, 29(3), 609-620.

Poppo, L., Zhou, K.Z., \& Li, J.J. (2016). When can you trust "trust"? Calculative trust, relational trust, and supplier performance. Strategic Management Journal, 37(4), 724741.

Root, E.R. (1994). Entry strategies for international markets. San Francisco, CA: Lexington Books.

Rule, C., Rogers, V., \& del Duca, L. (2010). Designing a global consumer Online Dispute Resolution (ODR) system for cross-border small value-high volume claims-OAS developments. Uniform Commercial Code Law Journal, 42(3), 221.

Schellenberg, M., Harker, M. J. \& Jafari, A. (2018). International market entry mode-a systematic literature review. Journal of Strategic Marketing, 26(7), 601-627.

Schmitz, A. J. (2016). Building trust in ecommerce through online dispute resolution. In Research Handbook on Electronic Commerce Law. Edward Elgar Publishing.

Seggie, S. H. (2012). Transaction cost economics in international marketing: A review and suggestions for the future. Journal of International Marketing, 20(2), 49-71.

Sharma, V., \& Erramilli, M. (2004). Resource-based explanation of entry mode choice. Journal of Marketing Theory and Practice, 12(1), 1-18.

Shaver, J. (2013). Do we really need more entry mode studies? Journal of International Business Studies, 44(1), 23-27.

Shen, Z., Puig, F., \& Paul, J. (2017). Foreign market entry mode research: A review and research agenda. The International Trade Journal, 31(5), 429-456.

Song, J. (2017). China's cross-border e-commerce expected to hit \$1.32t in 2018. http://www.chinadaily.com.cn/business/2017-10/30/content 33890583.htm

Taylor, C. R., Zou, S., \& Osland, G. E. (1998). A transaction cost perspective on foreign market entry strategies of US and Japanese firms. Thunderbird International Business Review, 40(4), 389-412.

Tian, X. (2007). Managing international business in China. Cambridge: Cambridge University Press.

Wang, J. (2014). Opportunities and challenges of international e-commerce in the pilot areas of China. International Journal of Marketing Studies, 6(6), 141-149. 
Wang, L., Chai, Y., Liu, Y., \& Xu, Y. (2015). Qualitative analysis of cross-border ecommerce based on transaction costs theory. IEEE 12th International Conference on e-Business Engineering, Beijing, 166-172.

Walters, J., Kuo, Y., Jap, W., \& Hsu, H. (2011). The world's next e-commerce superpower, navigating China's unique online-shopping ecosystem. https://www.bcgperspectives.com/content/articles/retail_consumer_products_worl ds_next_ecommerce_superpower/

Walters, J., Gao, H., Hui, V., Wang, A., Yang, J., \& Lyu, Z. (2017). Five profiles that explain China's consumer economy. https://www.bcg.com/publications/2017/globalizationaccelerating-growth-consumer-products-five-profiles-that-explain-chinasconsumereconomy.aspx

Watson, C. M. (1982). Counter competition abroad to protect home markets. Harvard Business Review, 60(1), 40-42.

Whinston, M. D. (2003). On the transaction cost determinants of vertical integration. Journal of Law, Economics, and Organization, 19(1), 1-22.

Willcocks, L. (2013). Global Business Management Foundation, $2^{\text {nd }}$ edition. Stratfordupon-Avon: Steve Brookes Publishing

Williamson, O. E. (1975). Transaction-cost economics: The governance of contractual relations. Journal of Law and Economics, 22(2), 233-261.

Williamson, O. E. (1985). The economic institutions of capitalism. New York: Free Press.

$\mathrm{Xu}, \mathrm{S} .(2017 \mathrm{a})$. The ultimate guide to cross-border ecommerce in China: History and scale. https://grizzlypandamarketing.com/ultimate-guide-cross-border-ecommercechina-history-scale/

$\mathrm{Xu}, \mathrm{S}$. (2017b). The ultimate guide to cross-border ecommerce in China: How to choose right platform for your business. https://grizzlypandamarketing.com/ultimate-guidecross-border-ecommerce-china-choose-right-platform-business/

Xue, W., Li, D., \& Pei, Y. (2016). The development and current of cross-border ecommerce. WHICEB 2016 Proceedings. Paper 53, https://aisel.aisnet.org/whiceb2016/53/

Yin, R. K. (1994). Case study research: Design and methods. $2^{\text {nd }}$ edition. Thousand Oaks: Sage. 